\section{New Paradigms in Ecuador}

\section{Liz Reisberg}

Liz Reisberg is director of International Strategies and Training, and a doctoral student in higher education at Boston College. Address: 207 Campion Hall, Boston College, Chestnut Hill, MA 02167. USA. FAX: (617) 552-8422.

$\mathrm{T}$ he progression of higher education in Latin America sometimes seems like a roller coaster ride out of control. External forces have repeatedly changed the characteristics of most public institutions. During the past several decades dramatic shifts in political and economic agendas resulted in new priorities for public universities from one government to the next; growing demand for access resulted in a precipitous increase in enrollment at all institutions as well as the creation of new public universities; budgets for public universities weren't adjusted for either enrollment growth or inflation. As additional professors and staff were hired to accommodate increased enrollment, many university budgets were almost entirely consumed by salaries. Universities simultaneously faced deteriorating physical plants, anachronistic technology, inadequate or nonexistent libraries, and faculty without resources for updating their knowledge or credentials (through journal subscriptions, by pursuing advanced degrees, or any other means). Through the 1980s public universities in most of the region depended almost entirely on government financing and no additional funding was likely to be forthcoming; national governments had embraced new economic ideologies with little affection for massive public subsidies. Yet in a region with a strong tradition of political activism on campus, a new paradigm was not necessarily welcome.

\section{The diversification of funding sources for public institutions is now a regional an- them.}

The diversification of funding sources for public institutions is now a regional anthem. Governments from the Rio Grande to Tierra del Fuego have adopted new economic policies, but those who write policy rarely have to face the day-to-day challenges of running a university. Today university rectors find themselves between the proverbial rock and a hard place with enormous challenges and few-if any-offers of help. Any new rector committed to providing high quality education that will prepare his or her students for the next millennium will have to invest heavily in human and physical resources. At the same time the traditional source of funds- the national governmenthas withdrawn much of its traditional support. This essay introduces two Ecuadorian rectors who have taken on this challenge. Their approaches-like their institutions-have many similarities as well as differences, but perhaps what is most noteworthy here is their courage to challenge tradition in the interest of protecting their institutions against the threat of mediocrity.

Taking on the Volatile Issue of Student Fees Nelson Cevallos and Rodrigo Arrobo each graduated from the university over which each presides today-Cevallos from the Escuela Superior Politécnica del Litoral (ESPOL) in Guayaquil and Arrobo from the Escuela Politécnica Nacional (the Politécnica) in Quito-the two leading public technical universities in Ecuador. The Politécnica is one of the oldest universities in Ecuador-founded in 1869while ESPOL is a relative newcomer-founded in 1958. A degree from either school has been a passage out of poverty for many talented young people; graduates have enjoyed considerable success in the public and private sectors. Both universities boast of a highly trained faculty, many of whom have earned graduate degrees abroad and had the chance to conduct research-opportunities that few professors can pursue any longer.

Both rectors recognized that there was a pressing need for new sources of revenue and an urgent need to restructure certain elements of the university to maximize the coverage of a seriously limited budget. Both men understood the necessity of increasing student fees. At the same time, they recognized the importance of protecting access for students from lower socioeconomic groups. Still, free higher education is a long-standing tradition in Latin Americaoften constitutionally guaranteed. It is not a tradition challenged lightly.

Perhaps because Cevallos and Arrobo are both engineers, they each pursued a fee plan based on a sophisticated formula using a number of variables-among these a factor that reflected the student's economic circumstances and an achievement index that would lower the fees charged to the students with the best performance. The fees charged to each student would thus vary with his or her economic circumstances, but a student would also be able to lower the fees through superior academic achievement.

Remarkably, Arrobo was in the process of collecting detailed data about his student body that would form the basis of his fee proposal when students in one of the schools at the Politécnica proposed their own fee plan. Students, frustrated by the outdated equipment they used, proposed that all students in their program pay a laboratory fee that 
would repair old and buy new equipment. The Consejo Politécnico, the highest governing authority of the university, not only approved the plan as proposed, but expanded it to the entire university. They stipulated that the fees collected in each program would be retained by each faculty to be invested in equipment. The fee issue contributed to growing political tensions on campus that led to a six-week strike called by the Student Federation. In campuswide elections, new student representatives were elected to the Consejo Politécnico. When the laboratory fee was considered, the vote was upheld. The predominant sentiment seemed to be in favor of improving conditions for learning-even if it meant fees. What is especially interesting in this case is that while the rector pursued-and continues to pursue-an equitable plan for charging fees, students themselves introduced a regressive fee that had sufficient support to survive the strike.

\section{The fees charged to each student would thus vary with his or her economic cir- cumstances, but a student would also be able to lower the fees through supe- rior academic achievement.}

Cevallos also faced student protest at ESPOL, but the demonstration barely lasted one day. As in the case of the Politécnica, when confronted with the alternative of continuing to work with outdated equipment and inadequate resources, students consented to the rector's plan.

In both cases, concessions were made to student demands-implementation schedules were adjusted, some changes were made in the fee structure-but in the end, the students and rectors had common goals. That students are willing to accept change to this canon of higher education, considered sacrosanct, may reflect a dramatic change between this generation and its predecessor.

\section{AdDitional ReForms}

Neither rector believed that student fees would be sufficient to cover the need for additional revenue. Other initiatives were required as well.

Cevallos relieved some of the strain on the budget by removing services from the university budget and contracting them out to providers in the private sector-e.g., maintenance, security, the university bookstore, and bus service. However, the key element of his plan was to reduce financial dependency on the government by dramatically increasing self-generated income. He did this by creating 27 new, self-financing degree programs, introducing a structure to reward individual faculty members and their departments for selling consulting services, renting university facilities to outside groups, and expanding a profit-making continuing education program. Many of his proposals bucked tradition and provoked passionate debate in the University Council, but Cevallos benefited from the extraordinary campuswide recognition of the necessity for change and gained the support he needed. In 1992-when Cevallos became rector-26 percent of ESPOL's operating budget was self-generated; by 1996-despite little change in the allocation from the government-Cevallos had increased the self-generated percentage of the operating budget to 56 percent.

\section{Neither rector believed that student fees would be sufficient to cover the need for additional revenue. Other initiatives were required as well.}

Arrobo became the rector of the Politécnica in late 1995. Like Cevallos, high among his priorities were several changes to take pressure off the operating budget. A critical part of his plan was to restructure the admissions program. In order to enroll in the Politécnica degree programs, students are required to pass a challenging examination. A very small percentage of test takers pass the examination. Most students enroll in a four-semester program to help them increase their skill and competence to the level required for upper-level degree study. Admission to the lower-level program has been on a first-come-firstserved basis. Over the years a strange phenomenon has evolved. Many of the students who fail to pass the exam, enroll in the predegree program, fail it as well, and then repeat the course. At present after seven semesters, only 20 percent of the students in the program are successful in proceeding to the upper division. With heavy demand to enroll and large numbers repeating, enrollment in the predegree program has surged. The increasing enrollment absorbs larger and larger portions of the operating budget each year, diverting resources from upper-level programs. As a result, students at one of the country's top technical universities are working with equipment that is often a decade out of date.

Arrobo introduced a plan that would reduce enrollment in the predegree program and reduce the length to one semester. The most controversial part of his plan, though, was the introduction of an admissions aptitude test 
that students would be required to pass before enrolling in the predegree program. His goal was to limit the program to those students who had a good possibility of passing it. The aptitude test contributed to the tensions that led to the strike. Open access and free higher education are sacred in much of Latin America and certainly in Ecuador. Arrobo challenged both ideals and succeeded in introducing new approaches.

\section{Conclusion}

This article doesn't begin to describe the complexity of the reforms these two rectors have undertaken. What is intended here is to highlight that new economic models have become central to the higher education equation. Yet the extreme financial constraints have made it possible for these two rectors to challenge certain characteristics of public higher education that have been considered "untouchable" in this century. There seems to be a new and more practical attitude on campus that makes difficult reforms possible. No one-administrators, professors, or students-wants to settle for the alternative: an education inadequate to the demands of a modern and global future.

\section{The University and Integration in Latin America}

\section{Axel Didriksson}

Axel Didriksson is coordinator of UNESCO's University and Integration Chair. Address: CISE, UNAM-Circuito Exterior, Ciudad Universidad, CP 045, Mexico DF, Mexico.

$\mathrm{O}$ ne of the most important events in Latin American academia in 1996 was the Regional Conference on Politics and Strategies in the Transformation of Higher Education in Latin America and the Caribbean, organized by UNESCO's Regional Center for Higher Education in Latin America and the Caribbean (CRESALC). International cooperation was the major issue on the agenda. The main outcome of the conference was the realization that Latin American and Caribbean higher education institutions will have to merge their efforts in order to overcome the obstacles they face. Commission Five was entrusted with the formulation of a proposal for reorienting international cooperation in the field of higher education.

The current Latin American context and its overall problems require analyzing several historical patterns of cooperation and, more particularly, the recent horizontally developed experiences. This new type of horizontal cooperation seeks to spur endogenous development conditions and establish operative formulas emanating from the co- operative practice itself. These experiences must spread in response to a period of structural changes requiring new patterns beyond traditional models. A new cooperation paradigm thus emerges, enriching the traditional relationships with the technical and/or financial assistance agencies in a "pairs and equals" situation rather than seeking to substitute them.

\section{The current Latin American context and its overall problems requires analyzing several historical patterns of coopera- tion and, more particularly, the recent horizontally developed experiences.}

Cooperation must then be geared toward surpassing existing asymmetries and establishing collaboration. It's very important to work within priority areas and proactive horizontal structures sharing resources, thus enabling innovative research, teaching, and coordination programs. CRESALC would seem to be the coordinating organization best suited to monitor and promote exchange intensification among higher education institutions by coupling its actions with the already existing networks and associations, and adapting its own structure and functions.

Using this context as a frame of reference, the commission recommended that:

- universities channel a specific portion of their budget toward horizontal regional cooperation;

- a web of networks be established emanating from the different joint experiences developed in the regionsuch as the Montevideo Group, the Amazonian, the Caribbean, and the Central American universities;

- academic consortia be fostered to share the requisite resources for cooperation;

- environment and sustainable development be made the top priorities of cooperation; and

- new social actors-i.e., gender, ethnic, linguistic, and class minorities-be actively involved in higher education change processes.

The commission also unanimously decided that CRESALC should be reconstituted into an autonomous institution for higher education in Latin America and the Caribbean. This new body will act as (1) an information, database and research center for the Latin American and Caribbean higher education system, and (2) a collegiate body of horizontal collaboration and cooperation where the continent's new cultural and intellectual capital will be developed and reproduced. 